\title{
Late Holocene variations in Pacific surface circulation and biogeochemistry inferred from proteinaceous deep-sea corals
}

\author{
T. P. Guilderson ${ }^{1,2}$, M. D. McCarthy ${ }^{2}$, R. B. Dunbar ${ }^{3}$, A. Englebrecht ${ }^{1}$, and E. B. Roark , $^{3}$ \\ ${ }^{1}$ Center for Accelerator Mass Spectrometry, Lawrence Livermore National Laboratory, Livermore, CA, USA \\ ${ }^{2}$ Institute of Marine Sciences and Department of Ocean Sciences, University of California, Santa Cruz, CA, USA \\ ${ }^{3}$ Department of Environmental Earth System Science, Stanford University, Stanford, CA, USA \\ *now at: Department of Geography, Texas A\&M University, College Station, TX, USA
}

Correspondence to: T. P. Guilderson (tguilderson@1lnl.gov, tguilder@ucsc.edu)

Received: 16 January 2013 - Published in Biogeosciences Discuss.: 28 February 2013

Revised: 27 July 2013 - Accepted: 30 July 2013 - Published: 12 September 2013

\begin{abstract}
N}$ and $\delta^{13} \mathrm{C}$ data obtained from samples of proteinaceous deep-sea corals collected from the North Pacific Subtropical Gyre (Hawaiian Archipelago) and the central equatorial Pacific (Line Islands) document multidecadal to century-scale variability in the isotopic composition of surface-produced particulate organic matter exported to the deep sea. Comparison of the $\delta^{13} \mathrm{C}$ data, where Line Islands samples are $0.6 \%$ more positive than the Hawaiian samples, supports the contention that the North Pacific Subtropical Gyre is more efficient than the tropical upwelling system at trapping and/or recycling nutrients within the mixed layer. $\delta^{15} \mathrm{~N}$ values from the Line Islands samples are also more positive than those from the central gyre, and within the Hawaiian samples there is a gradient with more positive $\delta^{15} \mathrm{~N}$ values in samples from the main Hawaiian Islands versus the French Frigate Shoals in the Northwestern Hawaiian Islands. The gradient in the Hawaiian samples likely reflects the relative importance of algal acquisition of metabolic $\mathrm{N}$ via dissolved seawater nitrate uptake versus nitrogen fixation. The Hawaiian sample set also exhibits a strong decrease in $\delta^{15} \mathrm{~N}$ values from the mid-Holocene to present. We hypothesize that this decrease is most likely the result of decreasing trade winds, and possibly a commensurate decrease in entrainment of more positive $\delta^{15} \mathrm{~N}-\mathrm{NO}_{3}$ subthermocline water masses.
\end{abstract}

\section{Introduction}

The central subtropical gyres comprise approximately $40 \%$ of the ocean's surface and historically, given their low dissolved nutrient concentrations, have been perceived as desolate deserts. The last two decades of ocean observations have shown that this is not the case. While much of the carbon and nutrients $(\mathrm{N}, \mathrm{P}, \mathrm{Si})$ fixed in the gyres are recycled within the mixed layer, about $10 \%$ of the primary productivity is exported out of the mixed layer to depth (Karl et al., 1996; Karl 1999). Recent evidence has shown that high spatial and temporal variability in primary production also exists (Dore et al., 2008; Church et al., 2009; Karl et al., 2002; Maranon et al., 2003). The sheer size of the gyres means that they can have a significant impact on global new production and the transport of carbon and other nutrients to depth, followed by possible remineralization or sequestration in sediments (Gruber et al., 1998; Karl et al., 2008; Quay and Stutsman 2003).

The Hawaiian Ocean Time-series (HOT) observations show that primary production in the gyres is not limited by the nitrogen (Eppley et al., 1977; Ryther, 1959) delivered by the upward flux of $\mathrm{NO}_{3}$ across the nutricline via diffusive and diapycnal entrainment events (Karl et al., 2008; Luo et al., 2012). The revised paradigm of the North Pacific Subtropical Gyre (NPSG), and the broader oceanic trades biome (Karl et al., 2008), incorporates significant nitrogen fixation by two microbial assemblages contributing to new production: a low and relatively constant nitrogen fixation rate by pico- and nanodiazotrophs, and a much higher rate by the 


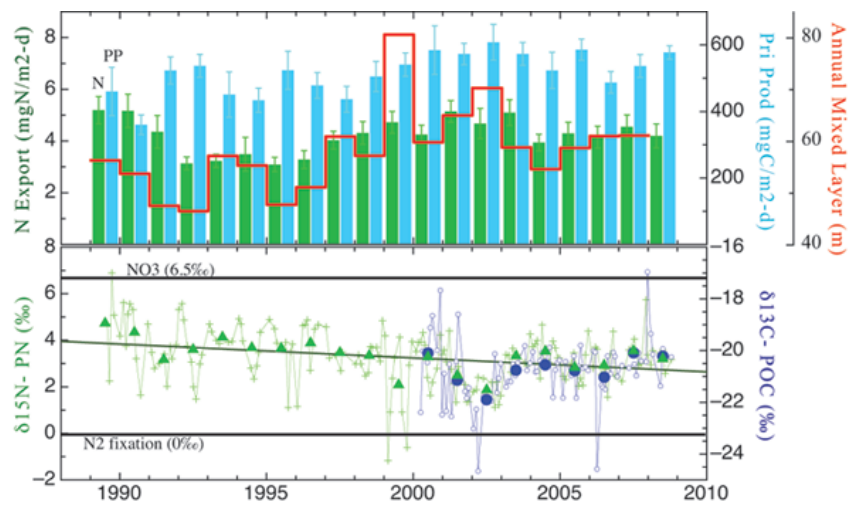

Fig. 1. Composite HOT-ALOHA data (http://hahana.soest.hawaii. edu/hot/hot-dogs/) including (upper panel) nitrogen export, primary productivity, annual mixed-layer depth and (lower panel) $\delta^{15} \mathrm{~N}$ and $\delta^{13} \mathrm{C}$ of sinking POC.

diazotroph Trichodesmium (Church et al., 2009; Karl et al., 2008). Unicellular bacteria contribute to nitrogen fixation primarily during fall and winter months, whereas filamentous microorganisms (cyanobacteria and Trichodesmium) appear to be most important during summer blooms. Although nitrogen fixed by these taxa is only a few percent of total nitrogen use, it is a very significant (nearly half) contributor to annual new nitrogen (Church et al., 2009; Dore et al., 2002, 2008; Karl et al., 2008).

Global oceanic primary productivity appears to have declined over the past century, at the same time that sea surface temperatures have risen (Boyce et al., 2010). This is interpreted to reflect increasing hydrographic stability and reduced nutrient flux into the mixed layer. In contrast with the global trend of reduced primary productivity, in the North Pacific (and NPSG) marine productivity has slightly increased (Boyce et al., 2010). This large-scale observation is verified at HOT Station ALOHA (Fig. 1), where primary productivity has increased at a rate of $7.3 \pm 1.3 \mathrm{mgC} \mathrm{m}^{-2} \mathrm{~d}^{-1}$ ( $r=0.6$ ) over the last $\sim 20 \mathrm{yr}$. This is in addition to the near doubling of productivity of HOT-ALOHA relative to the CLIMAX study period (1965-1985) (Karl, 1999) thought to be associated with the Pacific Decadal Oscillation regime shift of 1976. Additionally, mean annual mixed-layer depth has increased by $0.7 \mathrm{~m} \mathrm{yr}^{-1}(r=0.5)$, with winters seeing a larger depth increase than summers (cf. Quay and Stutsman, 2003). However, over the $\sim 20 \mathrm{yr}$ of observations, the nitrogen export as sinking particulate organic carbon (POC) flux has only a small and relatively weak secular trend $\left(0.06 \mathrm{mgN} \mathrm{m}^{-2} \mathrm{~d}^{-1}, r=0.16\right)$.

The $\delta^{15} \mathrm{~N}$ of particles exported out of the mixed layer at HOT, which at steady state records the isotopic value of "new nitrogen", exhibits an $\sim 7 \%$ range, and the flux weighted mean annual values have varied by $\sim 3 \%$ over the past $20 \mathrm{yr}$ (Fig. 1). There is an opposing and significant secular trend in $\delta^{15} \mathrm{~N}$ values $\left(-0.06 \% \mathrm{yr}^{-1} ; r=0.56\right)$, and also a linear re- lationship between $\delta^{15} \mathrm{~N}$ of new production and overall primary productivity $(r=0.7)$, where less positive $\delta^{15} \mathrm{~N}$ corresponds to higher primary productivity. The variability in $\delta^{15} \mathrm{~N}$ may in part reflect a much steeper rate of change prior to $\sim 2002$ (Dore et al., 2002), followed by a "reset" event of unknown origin (cf. Corno et al., 2007; Karl et al., 2008). The $\mathrm{NO}_{3}^{-}$entering the mixed layer from the nutricline has a $\delta^{15} \mathrm{~N}$ value of $\sim 6.5 \%$, while that formed from nitrogen fixation has a $\delta^{15} \mathrm{~N}$ value near $0 \%$ (Casciotti et al., 2008; Corno et al., 2007; Dore et al., 2002, 2008). Therefore, the balance of $\mathrm{NO}_{3}^{-}$uptake versus fixation of new nitrogen supporting production is reflected in the $\delta^{15} \mathrm{~N}$ value of exported particulate nitrogen. Together, these trends imply that the observed increase in primary productivity is the result of increased summer productivity supported by nitrogen fixation. This interpretation is supported by observations of summer blooms composed of Trichodesmium and other nitrogen fixing cyanobacters within the mixed layer, but well above the nutricline (Church et al., 2009; Karl et al., 2008, and references therein), and also both stoichiometric assessments of $\mathrm{N}$ and $\mathrm{P}$ dissolved and particulate pools (including $<10 \mathrm{~nm}$ $\mathrm{NO}_{3}$ concentrations; cf. Karl 1999; Karl et al., 2008, among others) and in situ $\mathrm{N}_{2}$ fixation rates (e.g., Dore et al., 2002).

However, without a longer-term spatial and temporal context for these observations, it is very difficult to delineate the role of ecosystem changes vs. variable nutrient sources, or to understand if trends at HOT are linked to current global changes, or if they may simply reflect multidecadal-scale natural fluctuation. Using deep-sea sediments for this purpose is difficult as the flux of material to abyssal depths is severely reduced by remineralization in both the water column and at the seafloor, such that the ultimately "archived" material typically contains $<1 \%$ of the original exported production (e.g., Wakeham, 1997). Open-ocean cores in this region have very low accumulation rates (in general $\leq 2 \mathrm{~cm} \mathrm{kyr}^{-1}$ ), and are subject to significant bioturbation, which together vastly reduces the possible temporal resolution (e.g., Wheatcroft 1990). Further, microbial degradation, trophic transfer, and diagenetic effects (e.g., Altabet 1988, 2001, among many) can also act in concert to further confound the isotopic signal and thus the interpretation of what has occurred in the overlying surface waters. It is therefore necessary to turn to new archives to place the HOT and other instrumental observations in a longer context.

Deep-sea corals occur in all of the world's oceans at depths ranging from 0-6200 $\mathrm{m}$ (Stanley and Cairns, 1988). Within the myriad of "deep-sea corals" are several taxa whose skeletons are completely or partly composed of a hard horny protein (gorgonin), that is well preserved and resistant to diagenesis (e.g., Sherwood et al., 2006). This group includes Primnoa, various bamboo genera (Isidella, Keratoisis), black (e.g., Antipathes) corals, and the gold coral Gerardia. Gerardia sp, as it has been colloquially known, is also a recognized synonym for Savalia sp. Although studies are shedding light 
on the genetic relationships among related species (Sinninger et al., 2013), the taxonomy is still evolving. Gerardia is a cosmopolitan colonial zoanthid that forms tree-like structures with heights of several meters and basal attachment diameters up to a few $10 \mathrm{~s}$ of $\mathrm{cm}$. Gerardia have radial growth rates of $<100 \mu \mathrm{m} \mathrm{yr}^{-1}$ and can attain "life spans" of centuries to millennia (Roark et al., 2006, 2009). In Hawaiian waters they are most abundant at $\sim 450 \mathrm{~m}$, near the top of the regional low oxygen zone, and are directly attached to exposed, hard substrates. Radiocarbon $\left({ }^{14} \mathrm{C}\right)$ analyses of polyps and a finely sectioned radial skeletal disk of a live harvested branch both document incorporation of recently exported particulate organic carbon (Roark et al., 2009), while stable isotope analysis shows that polyps are $\leq 2$ trophic levels relative to exported POC/PON (Roark et al., 2009). The close coupling between organic matter export and the growth of gorgonin in proteinaceous deep-sea coral skeletons indicates that these organisms are a source of information on past surface biogeochemistry changes of potentially unsurpassed fidelity (cf. Heikoop et al., 2002; Roark et al., 2005, 2009; Sherwood et al., 2005, 2009, 2011; Williams et al., 2006).

\section{Methods}

Deep-sea coral samples, both living and fossil, were collected using the Hawaiian Undersea Research Laboratory's DSRV Pisces $I V$ and $V$. Results presented here include mainly samples collected from the Hawaiian Archipelago in 2004 and 2007 (Big Island, Cross Seamount, Oahu in the Main Hawaiian Islands (MHI), and French/East French Frigate Shoals and Brooks Bank in the North West Hawaiian Islands (NWHI)), as well as a smaller sample set from Kingman Reef and Palmyra in the Line Islands $\left(\sim 6^{\circ} \mathrm{N}\right.$, $161^{\circ} \mathrm{W}$ ) (Fig. 2) collected in 2005 . Upon recovery, the external polyps and tissue were removed using a seawater hose from all live-collected individuals. After removing the tissue layer, the skeletons (live collected and subfossil) were washed with seawater followed by fresh water and allowed to air dry on deck. Stumps were cut into $\sim 0.7 \mathrm{~cm}$ thick cross section disks taken close to the basal attachment. In a small number of cases additional disks were also taken higher on the branch (or stump) to confirm growth longevity and radial growth rate. "Range finder" sampling, to determine the age range of the fossil skeletons, was done by microdrilling center (inner) and outer samples from radial transects using a $1.8 \mathrm{~mm}$ spherical carbide bur. Depending on the size of the cross section disk, subsamples between the inner and outer samples were also taken.

Milled samples were decarbonated using $1 \mathrm{~N} \mathrm{HCl}$, rinsed three-times with Milli-Q water and dried overnight on a heating block. Subsamples were transferred to tin boats and the mass determined. Carbon and nitrogen stable isotope analyses were made via continuous-flow isotope-ratio mass spectrometry (IRMS) using a Carlo-Erba elemental analyzer con-

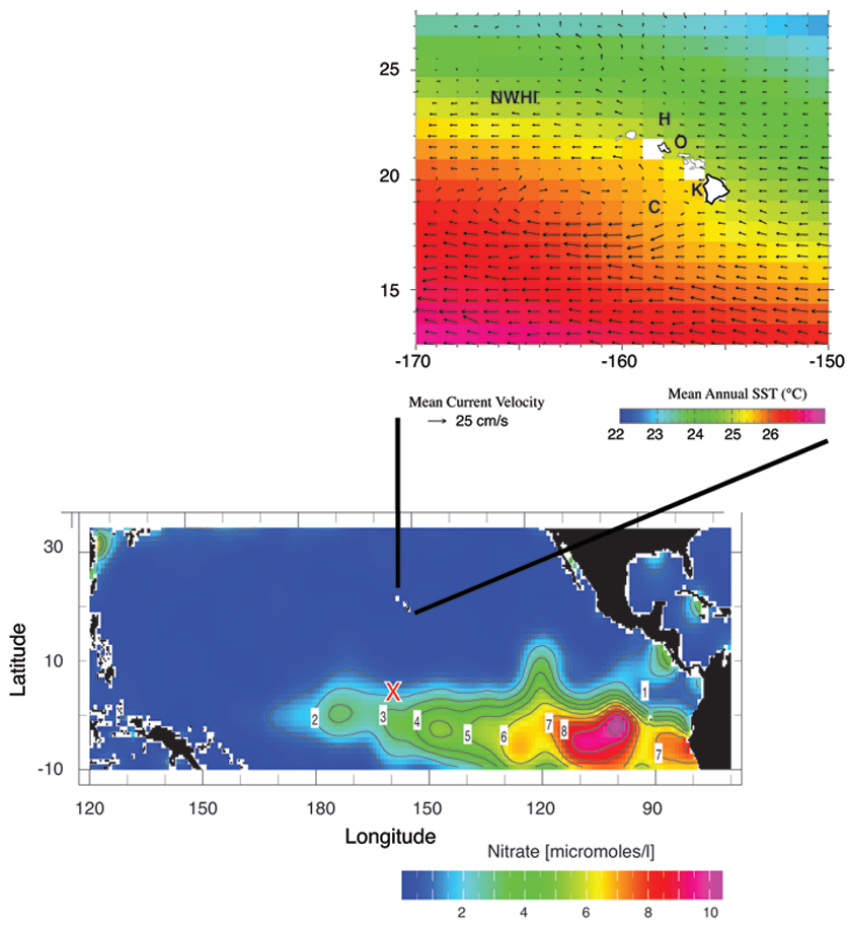

Fig. 2. Annual surface nitrate $\left(\mu \mathrm{mol} \mathrm{L}{ }^{-1}\right)$ concentration (NODC World Ocean Atlas 2009 accessed via iridl.ldeo.columbia.edu/SOURCES/.NOAA/.NODC/.WOA09/), " $X$ " denotes Kingman Reef/Palmyra Island complex. Inset figure: mean annual sea surface temperatures (WOA, 2009) and surface currents. Locations discussed in the text: HOT-ALOHA (H), Cross Seamount (C), Big Island - windward (K), Oahu - leeward (O), and the Northwest Hawaiian Islands (NWHI) which includes samples from near French Frigate Shoals (French and East French Frigate Shoals, Brooks Bank).

nected to an Optima IRMS in the UCSC Light Isotope Facility. Results are reported in conventional per mil notation relative to VPDB $\left(\delta^{13} \mathrm{C}\right)$ and air $\left(\delta^{15} \mathrm{~N}\right)$. Reproducibility of the isotope results is $\pm 0.12 \%$ and \pm 0.06 ( $1 \mathrm{sd}$ ) based on reproducibility of standards (acetanilide, $n=20$ ) and replicate analyses $(n=29)$ of coral samples for $\delta^{13} \mathrm{C}$ and $\delta^{15} \mathrm{~N}$, respectively. $\mathrm{C}: \mathrm{N}$ ratios determined during analysis were \pm 0.15 ( $1 \mathrm{sd})$.

Radiocarbon subsamples were first converted to $\mathrm{CO}_{2}$ via sealed-tube combustion, and the resulting purified $\mathrm{CO}_{2}$ reduced to graphite in the presence of an iron catalyst. Individual graphite-catalyst mixtures were pressed into aluminum target holders and analyzed via accelerator mass spectrometry. Results include a background subtraction based on similarly prepared ${ }^{14} \mathrm{C}$-free coal and wood, and sample-specific $\delta^{13} \mathrm{C}$ corrections, and are reported as conventional radiocarbon years as per Stuiver and Polach (1977). Conventional radiocarbon years were converted to calendar ages using the IntCal09 data product (Reimer et al., 2009). For Hawaiian samples, and based on a $\sim 40 \mathrm{yr}$ average of reef-building 
hermatypic coral data, a $\Delta \mathrm{R}$ of $-28 \pm 4$ was used (Druffel et al., 2001). For the Line Islands we use $0 \pm 50 \mathrm{yr}$, which is consistent with reef-building coral results presented in $\mathrm{Za}$ unbrecher et al., (2010). Radiocarbon results of a subset of the Hawaiian samples included here have been previously reported in Roark et al. (2006, 2009).

\section{Results}

Range finder ages and implied radial growth rates for the Hawaiian samples are presented in Fig. 3a and for the Line Islands specimens in Fig. 3b. Average radial growth rate for the Hawaiian sample suite is $38 \pm 21 \mu \mathrm{m} \mathrm{yr}^{-1}(n=58)$, with age ranges per specimen collected of 225 to $2740 \mathrm{yr}$. The average radial growth rate of the Line Islands specimens is $33 \pm 15 \mu \mathrm{m} \mathrm{yr}^{-1}(n=14)$, with age ranges per specimen of 290-1600 yr. The distribution of specimen ages is clustered in the late Holocene $(<6000 \mathrm{yr}$ BP). At Cross Seamount we collected a specimen dated from the late deglacial, $\sim 10500$ to $\sim 11300$ calendar years BP. The majority of the samples are subfossil branches and not trunks. These data therefore represent minimum age ranges and should not be used to estimate population dynamics and ultimate longevity. Based on the average linear growth rate and the milled sample size, isotopic results are representative of $50-100 \mathrm{yr}$ integrations. The average C : N ratio of all Gerardia samples was $2.82 \pm 0.16$.

Over the past $6000 \mathrm{yr}$, the $\delta^{13} \mathrm{C}$ of the Line Islands specimens tend to have more positive values $(-15.9 \pm 0.4 \%$, $n=39)$ relative to the Hawaiian samples $(-16.5 \pm 0.6 \%$, $n=47$ ) (Fig. 4a). Over the late Holocene there is no obvious secular trend to the $\delta^{13} \mathrm{C}$ values $(r=<0.01,0.13$ for the Line Islands and Hawaiian Islands, respectively). However, the deglacial specimen from Cross Seamount exhibits a $\delta^{13} \mathrm{C}$ increase from -18 to nearly $-16 \%$ from 11300 to 10500 cal years BP (Fig. 4a, $r=0.89$ ).

The $\delta^{15} \mathrm{~N}$ values of Line Islands samples exhibit no trend $\left(8.3 \pm 4.8 \times 10^{-6} \% \circ \mathrm{yr}^{-1}, r=0.03\right)$, and over the late Holocene are substantially more positive than all of the NPSG samples, particularly those from the NWHI (Line Islands: $+16.9 \pm 0.5 \%, n=39$ vs. NWHI: $+9.4 \pm 0.8 \%$, $n=47$ ) (Fig. 4b). Within the Hawaiian Archipelago there is also a much smaller geographic trend in values, where samples from the southern and main islands are more positive and those from the NWHI are less positive (Fig. 4b; Big Island/Cross Seamount: $+12 \pm 1 \%$; Lanikai: $+10.9 \pm 0.6 \%$; NWHI: $+9.4 \pm 0.8 \%$ ). In contrast with the Line Islands samples, most records from the Hawaiian Islands exhibited significant temporal trends. In a specimen from Cross Seamount spanning 11300-10500 calendar years BP, we document a $4 \% \circ \delta^{15} \mathrm{~N}$ increase, beginning at $\sim 11 \%$ at $11.3 \mathrm{kyr} \mathrm{BP}$ and peaking at $\sim 15 \%$ before decreasing slightly at $10.5 \mathrm{kyr}$ BP. Unfortunately, no samples span the interval between 10500 and $\sim 3850$ calendar years BP from this location. Values from samples at $\sim 3850$ cal-
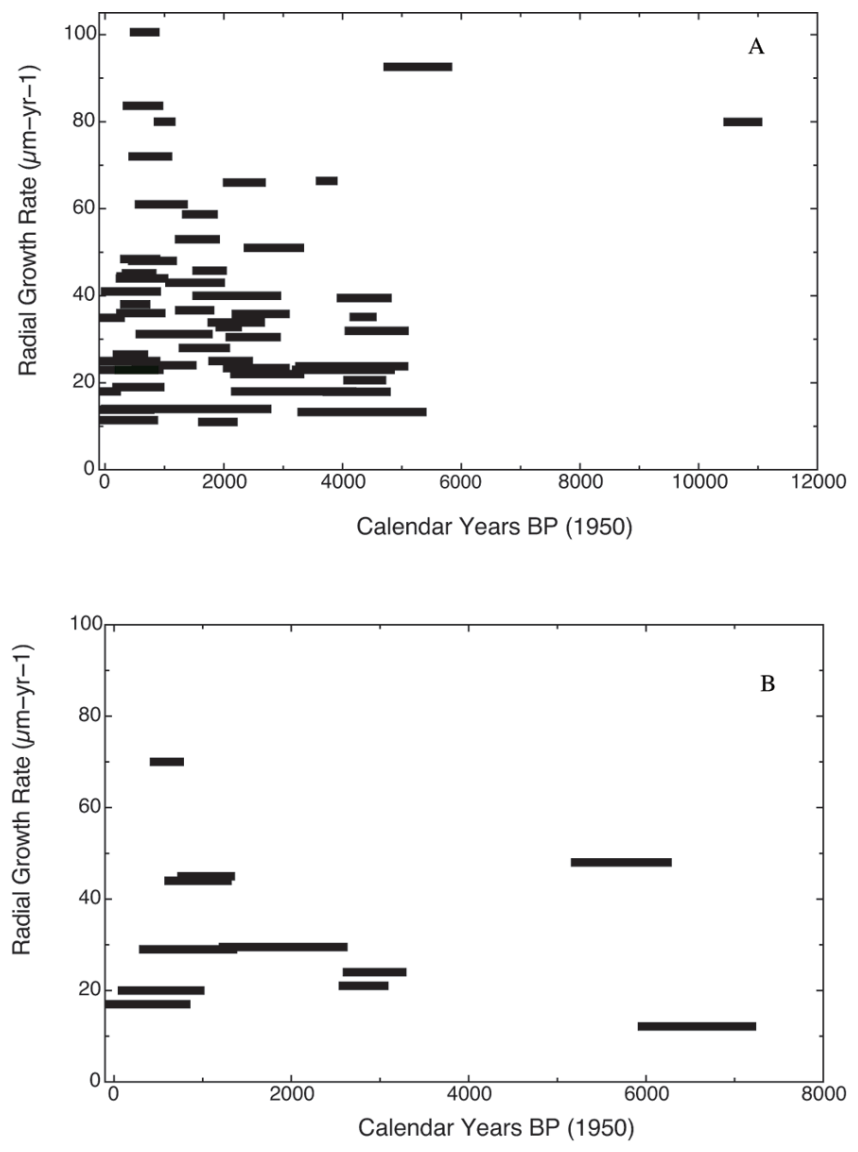

Fig. 3. (A) Upper panel: Hawaiian Gerardia longevity (calendar years BP) and average radial growth rate $\left(\mu \mathrm{m} \mathrm{yr}^{-1}\right)$; and (B) lower panel: equivalent plot for Line Islands samples.

endar years BP are similar to those at 10500 calendar years BP, however they systematically decrease through the present day, with values of $\sim 10.6 \%$ ofor ${ }^{14} \mathrm{C}$ modern gorgonin $\left(8.9 \times 10^{-4} \pm 1.1 \times 10^{-5} \% \mathrm{yr}^{-1}, r=0.87, n=27\right.$, $p<0.005)$. Similar decreases in $\delta^{15} \mathrm{~N}$ values in the late Holocene, although of differing magnitudes, are also observed at all other $\mathrm{HI}$ and NWHI sites. A $\sim 1.5 \%$ o decrease between $\sim 5080$ and $\sim 350$ calendar years BP is observed at the Big Island $\left(3.3 \times 10^{-4} \pm 7.3 \times 10^{-6} \%\right.$ o $\mathrm{yr}^{-1}$, $r=0.62, n=34, p<0.005)$. Samples from the windward side of Oahu, spanning $\sim 570-5500$ calendar years BP, also experience a smaller and nearly insignificant decrease in $\delta^{15} \mathrm{~N}$ values $\left(6.4 \times 10^{-5} \pm 7.4 \times 10^{-5} \%\right.$ o yr ${ }^{-1}, r=0.18$, $n=24$ ) over the same interval. Finally, samples from the NWHI $(\sim 5780$ calendar years BP to present $)$ exhibit more variability than the other Hawaiian locations, and record a decrease in $\delta^{15} \mathrm{~N}$ of just over $1 \%$, equivalent to $2.0 \times 10^{-4} \pm 0.07 \times 10^{-5} \% \mathrm{yr}^{-1}, r=0.38, n=47$, $p<0.01)$.

There are very few detailed studies that explicitly describe the potential impact of changes in trophic structure on sinking POC (either sedimentary or in proteinaceous corals) 

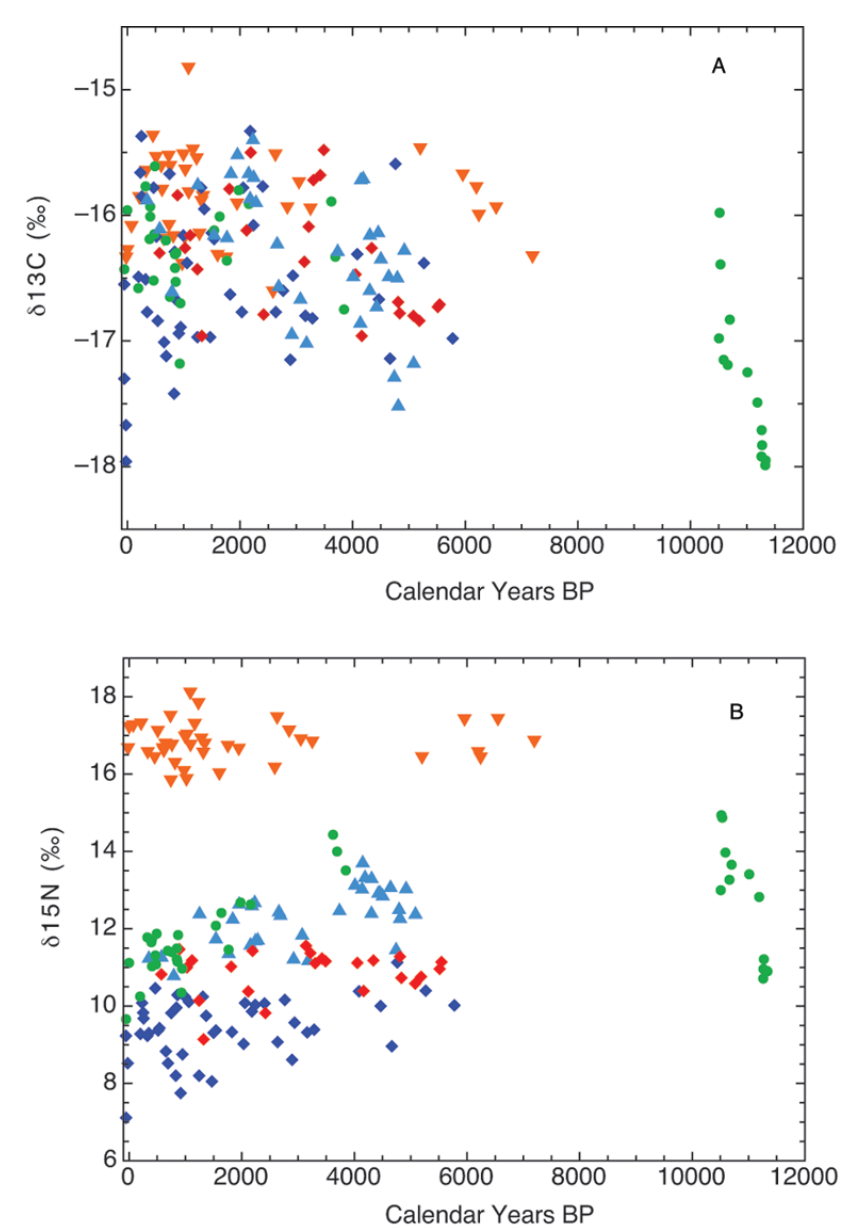

$\nabla$ Line Islands $\quad$ Cross Seamount

- Oahu (windward)

A Big Island (leeward)

- Northwest Hawai'ian Islands

Fig. 4. (A) Upper panel: bulk Gerardia $\delta^{13} \mathrm{C}$ (\%o VPDB); and (B) lower panel: $\delta^{15} \mathrm{~N}$ (\%o air) as a function of time and location. Each sample represents approximately $50-100 \mathrm{yr}$.

when interpreting stable isotope $\left({ }^{13} \mathrm{C}\right.$ and $\left.{ }^{15} \mathrm{~N}\right)$ results. The assumption has been that trophic changes (and diagenesis) are minimal. Given the shallowness of our sample suite (in general $\sim 450 \mathrm{~m}$ or less), we can probably neglect diagenesis of sinking POC. We currently assume that the trophic structure remained constant through time, but this will need to be validated (e.g., Sherwood et al., 2011).

\section{Discussion}

\subsection{Carbon $\left(\delta^{13} \mathrm{C}\right)$ isotopes}

Over the time interval for which we have data (late Holocene $\sim 5000 \mathrm{yr}$ BP to present), the Line Islands specimens average $0.6 \%$ more positive than the NPSG samples: $-15.9 \pm 0.4 \%$ o $(n=39)$ versus $-16.5 \pm 0.6 \%$ o $(n=$ 47) $(p<0.0001)$. There are no consistent trends as a func- tion of time in either dataset. The inferred late Holocene $\geq 0.5 \%$ o latitudinal gradient is larger than observed from modern surface $\delta^{13} \Sigma \mathrm{CO}_{2}$ analyses (e.g., Kroopnick 1974, 1985; Quay and Stutsman, 2003). Modern sinking particulate organic carbon in the equatorial region and the NPSG have similar values: in the range of -18 to $-22 \%$ (Altabet 2001; Georicke and Fry, 1994; Laws et al., 1995), with a flux weighted average of $-21 \%$ for HOT samples (cf. Fig. 1). The Line Islands experience seasonal to interannual sea surface temperature (ocean dynamics) and nutrient variability associated with El Niño-Southern Oscillation (ENSO) variations and on longer timescales (e.g., Tourre et al., 2001). This dynamic variability has the potential to impart undersampling biases in discrete samples, even in one to two year sediment trap programs.

The Line Islands are within the equatorial waveguide where upwelling of high nutrient, low $\delta^{13} \Sigma \mathrm{CO}_{2}$ water occurs in the eastern equatorial Pacific, as well as locally, but due to iron limitation nutrients are not completely consumed. Westward advection of the upwelled water, with continued phytoplankton preferential fixation/consumption of ${ }^{12} \mathrm{C}$, allows the surface reservoir to become enriched in ${ }^{13} \mathrm{C}$ with increasing distance from the upwelling center (e.g., Zhang and Quay, 1997). A leaky system, one that exports POC (with more negative $\delta^{13} \mathrm{C}$ values relative to $\Sigma \mathrm{CO}_{2}$ ) out of the mixed layer, will (therefore) leave the remaining $\Sigma \mathrm{CO}_{2}$ pool with more positive $\delta^{13} \mathrm{C}$ values. Efficient recycling of POC and nutrients in the NPSG would minimize net ${ }^{12} \mathrm{C}$ flux out of the mixed layer, yielding values that are less enriched relative to the original dissolved inorganic carbon "stock". We argue that the density of modern POC and dissolved inorganic carbon (DIC) data from the equatorial region is not sufficient to unequivocally define a $\sim 0.5 \%$ o regional difference in sinking POC or DIC over long (multidecadal) timescales, whereas the observations presented herein are. The latitudinal $\delta^{13} \mathrm{C}$ gradient recorded in Gerardia implies that "nutrient trapping" or mixed-layer nutrient recycling in the equatorial region is less efficient than in surface waters of the NPSG.

The late deglacial sample (Cross Seamount) records a nearly monotonic $2 \%$ increase in $\delta^{13} \mathrm{C}$ values between $\sim 11500$ and $\sim 10300 \mathrm{kyr}$ BP, i.e., at the very end of the Younger Dryas-Preboreal transition. This shift exceeds the $\sim 0.5 \%$ o increase observed in $\mathrm{CO}_{2}$ trapped in ice cores (Taylor Dome, Smith et al., 1999) and thus cannot strictly be explained by air-sea $\delta^{13} \mathrm{C}-\mathrm{CO}_{2}$ equilibration. This shift is also counter to the temperature effect of $\delta^{13} \mathrm{C}$ composition expected during the transition from cooler (glacial/Younger Dryas) to warmer (Preboreal) time. During the deglaciation along nearly the whole of the west coast of North America, a consistent pattern of increased burial of organic carbon occurred in the oxygen minimum zone (e.g., Dean et al., 2006; Kienast et al., 2002). We offer an explanation based on changes in carbon burial rates where sequestration of the isotopically more negative organic carbon $(\sim-20 \%$ ) would tend to increase the $\delta^{13} \mathrm{C}$ of the remaining DIC pool. The 
Table 1. Trends in late Holocene Gerardia $\delta^{15} \mathrm{~N}$ values as a function of location.

\begin{tabular}{lllll}
\hline Location & $\begin{array}{l}\text { Youngest } \\
(\text { cal yr BP })\end{array}$ & $\begin{array}{l}\text { Oldest } \\
(\text { cal yr BP })\end{array}$ & $\begin{array}{l}\text { Trend } \\
\left(\% \circ \mathrm{yr}^{-1}\right)\end{array}$ & $r$ \\
\hline Line Islands & Post-bomb & 7200 & $8.3 \pm 4.8 \times 10^{-6}$ & 0.03 \\
NWHI & Post-bomb & 5800 & $2.0 \times 10^{-4} \pm 0.07 \times 10^{-5}$ & 0.38 \\
Lanikai & 570 & 5550 & $6.4 \times 10^{-5} \pm 7.4 \times 10^{-5}$ & 0.18 \\
Big Island & 350 & 5100 & $3.3 \times 10^{-4} \pm 7.3 \times 10^{-6}$ & 0.62 \\
Cross Seamount & Post-bomb & 3850 & $8.9 \times 10^{-4} \pm 1.1 \times 10^{-5}$ & 0.87 \\
\hline
\end{tabular}

Cross Seamount $\delta^{15} \mathrm{~N}$ data (Fig. 4) provides further evidence for the $\delta^{13} \mathrm{C}$ change as a signal that is propagated into the NPSG from the margin via advection and entrainment of subthermocline water masses. The $\delta^{15} \mathrm{~N}$ pattern between 11500 and $10300 \mathrm{kyr} \mathrm{BP}$ is, in fine-scale detail, similar to that observed in oxygen minimum zone sediments (e.g., Kienast et al., 2002). Based on transient tracer data, the timescale of lateral advection and isopycnal diffusion of NPSG thermocline and subthermocline waters is several decades (e.g., Fine et al., 1987; Warner et al., 1996). This timescale is sufficient to allow for advection of $\delta^{15} \mathrm{~N}-\mathrm{NO}_{3}$ signals from the low oxygen zones in the eastern Pacific having substantial denitrification (e.g., Rafter et al., 2011, and references therein) into the NPSG.

\subsection{Nitrogen $\left(\delta^{15} \mathrm{~N}\right)$ isotopes}

The Palmyra and Kingman Reef samples have an average value of $+16.9 \%$ o (gorgonin) relative to $\sim+8 \%$ o for sinking POC near Palmyra (Altabet, 2001). Polyp and gorgonin $\delta^{15} \mathrm{~N}$ are expected to be similar (Heikoop et al., 2002; Roark et al., 2009). Thus, these offsets allow us to infer that, like Hawaiian Gerardia, the Line Islands Gerardia are low order consumers.

The nitrogen isotope values of the Line Islands specimens do not exhibit a trend over the last $\sim 7000 \mathrm{yr}$, but do include 2-3\%o variability recorded by individual multidecadal average samples. An explanation for this is suggested by variable nitrogen dynamics observed in the modern ocean. During the JGOFS EqPac/EPOC experiments, surface nitrate concentrations were found to vary by a factor of two, with five-fold variations in nitrogen flux, whereas suspended and sinking POC $\delta^{15} \mathrm{~N}$ was much less variable (Altabet, 2001). An exception was observed in sediment trap samples collected at $5^{\circ} \mathrm{N}$ and $2^{\circ} \mathrm{N}$, where a $\sim 5 \%$ change in $\delta^{15} \mathrm{~N}$ of sinking POC approximately covaried with nitrogen flux, spanning the termination of the 1992 El Niño event. This shift is the consequence of changing surface circulation when an El Niño transitions to "normal" or La Niña conditions bringing a northward expansion of recently upwelled (higher nutrient) water and intensification of the North Equatorial Current.

Although ENSO variability cannot explain all tropical oceanographic variability, it is a useful model to further ex- plore our paleo-observations. Based on the observations of Altabet (2001), the deep-sea coral data could be reflecting multidecadal variability of the relative frequency of El Niño events. Although the vertical gradient in $\delta^{15} \mathrm{~N}$ of water sourced by upwelling is weak (Rafter et al., 2011), we cannot, over long timescales, uniquely exclude systematic changes in $\delta^{15} \mathrm{NO}_{3}$ due to isopycnal and diapycnal mixing of waters sourced from the denitrifying zones of the eastern Pacific. Nearly invariant Holocene $\delta^{15} \mathrm{~N}$ time series have been derived from marine sedimentary sequences in the far eastern equatorial Pacific off Mexico (Ganeshram et al., 2000), implying that the $\delta^{15} \mathrm{NO}_{3}$ source has likely remained constant. The lack of a $\delta^{15} \mathrm{~N}$ trend over the last $\sim 7000 \mathrm{yr}$, at least within the resolution of our record, implies that there have not been systematic changes in diapycnal mixing, or if so, that it has been fortuitously accommodated.

In contrast to the Line Islands, the Hawaiian corals reveal an interesting geographic pattern of late Holocene $\delta^{15} \mathrm{~N}$ variability. A late Holocene decrease in $\delta^{15} \mathrm{~N}$ (secular trend) is strongest in the southern Hawaiian Islands (Cross Seamount $3 \%$ change; Big Island $1.5 \%$ change to $\sim 350 \mathrm{yr} \mathrm{BP}$ ), and less apparent in the NWHI (Table 1). Modern and near modern $\delta^{15} \mathrm{~N}$ values from Cross Seamount and the Big Island approach those of the NWHI. If we were to apply the HOT $\delta^{15} \mathrm{~N}$-productivity relationship, the trend to less positive $\delta^{15} \mathrm{~N}$ values would imply an increase in primary productivity to the west of the Big Island, at least to Cross Seamount, and little to no change in productivity in the NWHI and east of Oahu. Additionally, if we use the 1-D $\mathrm{NO}_{3}$-nitrogen fixation end-member model (Fig. 1), then the observed decrease in $\delta^{15} \mathrm{~N}$ implies an increase in nitrogen fixation in excess of $30 \%$ over the late Holocene. Midlatitude ice core dust records (e.g., Osterberg et al., 2008) indicate that the midHolocene had slightly higher dust input. Higher dust input, if anything, would be expected to stimulate $\mathrm{N}$-fixation leading to less positive $\delta^{15} \mathrm{~N}$ : i.e., a trend that is opposite to that which we observe. We therefore do not believe that the observed trend is the result of changes in dust deposition.

These interpretations, however, require constant $\delta^{15} \mathrm{~N}$ $\mathrm{NO}_{3}$ source values, which over these multimillennial timescales, far in excess of the advective timescale of subsurface waters, may not be valid. An alternate explanation to the 1-D $\mathrm{NO}_{3}$-nitrogen fixation model would be to consider 
changes in the source of $\mathrm{NO}_{3}$ as a function of water mass (cf. Fig. 4 in Casciotti et al., 2008). The decrease in $\delta^{15} \mathrm{~N}$ values observed at Cross Seamount and the Big Island could be accommodated by an increase in the proportion of Subtropical Salinity Maximum Water (STSMW; less positive $\delta^{15} \mathrm{~N}$ ) relative to Shallow Salinity Minimum and North Pacific Intermediate water (SSMW/NPIW; more positive $\delta^{15} \mathrm{~N}$ ). The lack of a similar decrease to the east of Oahu, as well as the trend in the NWHI, implies that the decrease in $\delta^{15} \mathrm{~N}$ values is associated with the permanent mesoscale anticyclonic eddy centered at $\sim 19^{\circ} \mathrm{N}$ (e.g., Flament, 1996), or the production of anticyclonic cold core eddies off the Hawaiian Islands which are accompanied by entrainment of higher nutrient water from below (e.g., Bidigare et al., 2003).

A reduction in the production of eddies could be the result of a reduction of the trade winds and an increased frequency of midlatitude frontal systems which tend to block the trades. In general, a complementary effect of a reduction in the trade winds is decreased rainfall. On seasonal, interannual, and decadal timescales, the Hawaiian Islands' rainfall is influenced by large-scale atmospheric circulation changes exemplified by the correspondence of wintertime (rainy season) drought associated with El Niño events, and over longer periods a strong relationship is observed with the negative phase of the Pacific Decadal Oscillation (Chu and Chen, 2005; Diaz and Giambelluca, 2012). Paleoclimate reconstructions from Oahu and Laysan (located in the far NWHI) indicate a reduction in precipitation since the mid-Holocene (Athens et al., 2007; Uchikawa et al., 2010). The most parsimonious explanation for the observed multimillennial-scale trends in $\delta^{15} \mathrm{~N}$ values may therefore be a reduction in trade winds, leading to reduced anticyclonic eddy production. This would have reduced the entrainment of more positive $\delta^{15} \mathrm{~N}_{-} \mathrm{NO}_{3}$ water masses from depth, although the possibility also exists for either a reduction in overall entrainment or sourcing of less positive $\delta^{15} \mathrm{~N}^{-\mathrm{NO}_{3}}$ waters that are more shallow. A reduction in trade winds and an overall drying in the Hawaiian region is also consistent with modeling studies which link the orbital pacing of the seasonal cycle of solar radiation during the mid-Holocene boreal summer insolation maximum (Clement et al., 2000). We note that since $\sim 7000 \mathrm{yr} \mathrm{BP} \mathrm{a} \sim 3 \% \circ \delta^{15} \mathrm{~N}$ decrease is observed in marine sediments from the western tropical Pacific near the Philippines (Kienast et al., 2008). Although the similarity in amplitudes may be coincidence, both records seem to be responding to a decrease in the trade winds. A reduction in the equatorial trade winds could conspire to change the amount of more positive $\delta^{15} \mathrm{NO}_{3}$ advected into the western equatorial Pacific from the east, and at the same time an increase in the stability of the water column and reduce entrainment events that would bring more positive $\mathrm{NO}_{3}$ into the mixed layer from depth.

However, even taking into account the secular decrease in $\delta^{15} \mathrm{~N}$, the variability in $\delta^{15} \mathrm{~N}$ from the NWHI samples was larger than any of the MHI locations. The mixed-layer currents in the lower NWHI near the French Frigate Shoals are extremely variable, and are dominated by mesoscale eddies, where the variability in current velocity amplitude exceeds the mean (Firing and Brainard, 2006). We hypothesize that in periods when $\delta^{15} \mathrm{~N}$ is more positive, the longer-term circulation is dominated by northwestward flow bringing the influence of higher $\delta^{15} \mathrm{~N}-\mathrm{NO}_{3}$ waters from the MHI to the French Frigate Shoals. In contrast, when $\delta^{15} \mathrm{~N}$ is less positive, longer-term circulation is likely dominated by southern and eastward flow from farther in the center of the gyre where $\delta^{15} \mathrm{~N}-\mathrm{NO}_{3}$ is dominated by nitrogen fixation.

\section{Conclusions}

Bulk $\delta^{13} \mathrm{C}$ analyses of Gerardia skeletal material, spanning the mid-late Holocene, document a $0.6 \%$ gradient between the Line Islands in the equatorial Pacific and samples from the Hawaiian Archipelago in the NPSG, where the values of Line Islands samples are more positive. During the mid-late Holocene there are no consistent trends in the data as a function of time. The $\geq 0.5 \%$ o latitudinal gradient is larger than observed from somewhat limited modern surface $\delta^{13} \Sigma \mathrm{CO}_{2}$ analyses. The fossil results are perhaps a better integrated signal particularly for the equatorial region which experiences large seasonal to interannual variability. With similar $\delta^{13} \mathrm{C}-\Sigma \mathrm{CO}_{2}$ as the source, these results imply that "nutrient trapping" in the equatorial region is less efficient than in the mixed layer of the NPSG.

The long-term $\sim 20 \mathrm{yr}$ average $\delta^{15} \mathrm{~N}$ of sinking POC at the Hawaiian Ocean Time-series is $+3.4 \pm 0.7$ with a (annualweighted) range of $\sim 3 \%$. The $50-100 \mathrm{yr} \delta^{15} \mathrm{~N}$ averages reconstructed from Gerardia skeletons spanning the past $6000 \mathrm{yr}$ indicate that multidecadal $\delta^{15} \mathrm{~N}$ variability in the Hawaiian Islands in the NPSG is of similar amplitude to the annual variability captured by HOT and related cruises. The $\delta^{15} \mathrm{~N}$ values in Hawaiian Gerardia skeletons document a general decrease in sinking POC $\delta^{15} \mathrm{~N}$ values since the midHolocene. Direct explanations for these data include both changes in primary production, relative increases in $\mathrm{N}$ fixation, as well as a systematic change in the $\delta^{15} \mathrm{~N}-\mathrm{NO}_{3}$ of subthermocline water masses, or an overall decrease in the entrainment of subthermocline waters or entrainment of waters that are more shallow (less positive $\delta^{15} \mathrm{~N}^{-\mathrm{NO}_{3}}$ ). Less entrainment of deeper and more positive $\delta^{15} \mathrm{~N}-\mathrm{NO}_{3}$ water masses, or a change to entraining shallower water masses, most likely also would have been associated with a decrease in the trade winds, and a decrease in the formation of anticyclonic eddies in the passages between the main and southern Hawaiian Islands. Modern observations, which show a strong atmospheric dynamic linkage between trade winds and precipitation, suggest that this decrease in trade winds was likely also accompanied by a decrease in precipitation, a feature observed in Hawaiian paleorecords.

A smaller dataset of late Holocene Gerardia-based $\delta^{15} \mathrm{~N}$ values from the Line Islands does not exhibit any long-term 
trend across the late Holocene. The $2-3 \%$ o $\delta^{15} \mathrm{~N}$ variability hints at multidecadal ENSO variability, through ocean dynamics, influencing the $\delta^{15} \mathrm{~N}$ of sinking POC at $\sim 5^{\circ} \mathrm{N}$.

Acknowledgements. We are particularly grateful to the captain and crew of the R/V Ka'imikai-o-Kanaloa, and the engineers and pilots of the Pisces $I V$ and $V$ research submersibles. Collection of the deep-sea coral samples was supported by NOAA's Hawaiian Undersea Research Laboratory with additional support provided by the National Geographic Society (7717-04). Analyses of the Hawaiian samples were funded by NOAA's Office of Global Programs (NA05OAR4310021 and NA05OAR4310017) and the Line Islands samples by the National Science Foundation (OCE-0551792 and OCE-0551481). Additional support was provided by NSF OCE-1061689. Radiocarbon analyses were performed under the auspices of the US Department of Energy (contract W-7405-Eng-48 and DE-AC52-07NA27344). We would like to thank two summer interns who helped section and prepare a number of the deep-sea coral specimens for analyses: Kate Dydak (Wake Forest University via the DOE SURE program) and Nicole Werner (a teacher at Classical Academy High School, Escondido, CA, via the Teacher's Research Academy). We thank Leif Thomas for discussing eddy-generating mechanisms with us. This manuscript benefited from constructive reviews from two anonymous reviewers. Isotope data will be archived at the NOAA-NGDC paleodatabase. This is LLNL-JRNL-609577.

Edited by: N. Ohkouchi

\section{References}

Altabet, M. A.: Variations in nitrogen isotopic composition between sinking and suspended particles: implications for nitrogen cycling and particle transformation in the open ocean, Deep-Sea Res. II, 35, 535-554, 1988.

Altabet, M. A.: Nitrogen isotopic evidence for micronutrient control of fractional $\mathrm{NO}_{3}$ utilization in the equatorial Pacific, Limnol. Oceanog., 46, 368-380, 2001.

Athens, J. S., Ward, J. V., and Blinn, D. W.: Vegetation history of Laysan Island, Northwestern Hawaiian Islands, Pacific Science, 61, 17-37, 2007.

Bidigare, R. R., Benitez-Nelson, C, Leonard, C. L., Quay, P. D., Parsons, M. L., Foley, D. G., and Seki, M. P.: Influence of a cyclonic eddy on microheterotroph biomass and carbon export in the lee of Hawaii, Geophys. Res. Lett., 30, 1318, doi:10.1029/2002GL016393, 2003.

Boyce, D. G., Lewis, M. R., and Worm, B.: Global phytoplankton decline over the last century, Nature, 466, 591-596, doi:10.1038/nature09268, 2010.

Casciotti, K. L., Trull, T. W., Glover, D. M., and Davies, D.: Constraints on nitrogen cycling at the subtropical North Pacific Station ALOHA from isotopic measurements of nitrate and particulate nitrogen, Deep-Sea Res. II, 55, 1661-1672, 2008.

Chu, P.-S. and Chen, H.: Interannual and interdecadal rainfall variations in the Hawaiian Islands, J. Climate, 18, 4796-4813, 2005.

Church, M. J., Mahaffey, C., Letelier, R. M., Lukas, R., Zehr, J. P., and Karl, D. M.: Physical forcing of nitrogen fixation and diazotroph community structure in the North $\mathrm{Pa}-$ cific subtropical gyre, Global Biogoechem. Cy., 23, GB2020, doi:10.1029/2008GB003418, 2009.

Clement, A. C., Seager, R., and Cane, M. A.: Suppression of El Nino during the mid-Holocene by changes in the Earths's orbit, Paleoceanography, 15, 731-737, doi:10.1029/1999PA000466, 2000.

Corno, G., Karl, D. M., Church, M. J., Letelier, R. M., Lukas, R., Bidigare, R. B., and Abbott, M. A.: Impact of climate forcing on ecosystem processes in the North Pacific Subtropical Gyre, J. Geophys. Res., 112, C04021, doi:10.1029/2006JC003730, 2007.

Dean, W. E., Zheng, Y., Ortiz, J. D., and VanGeen, A.: Sediment Cd and Mo accumulation in the oxygen minimum zone off western Baja California linked to global climate over the past $52 \mathrm{kyr}$, Paleoceanography, 21, PA4209, doi:10.1029/2005PA001239, 2006.

Diaz, H. F. and Giambelluca, T. W.: Changes in atmospheric circulation patterns associated with high and low rainfall regimes in the Hawaiian Islands region on multiple time scales, Glob. Planet. Change, 98/99, 97-108, 2012.

Dore, J. E., Brum, J. R., Tupas, L. M., and Karl, D. M.: Seasonal and interannual variability in sources of nitrogen supporting export in the oligotrophic subtropical North Pacific Ocean, Limnol. Oceanogr, 47, 1595-1607, 2002.

Dore, J. E., Letelier, R. M., Church, M. J., Lukas, R., and Karl, D. M.: Summer phytoplankton blooms in the oligotrophic North Pacific subtropical gyre: Historical perspective and recent observations, Prog. Oceanogr., 76, 2-38, doi:10.1016/j.pocean.2007.10.002, 2008.

Druffel, E. R. M., Griffith, S., Guilderson, T. P., Kashgarian, M., Southon, J., and Schrag, D. P.: Changes of subtropical North Pacific radiocarbon and correlation with climate variability, Radiocarbon, 43, 15-25, 2001.

Eppley, R. W., Sharp, J. H., Renger, E. H., Perry, M. J., and Harrison, W. G.: Nitrogen assimilation by phytoplankton and other microorganisms in the surface waters of the central North Pacific Ocean, Mar. Biol., 39, 111-120, 1977.

Fine, R. C., Peterson, W. J., and Ostlund, H. G.: The penetration of tritium into the tropical Pacific, J. Phys. Oceanography, 17, 553-564, 1987.

Firing, J. and Brainard, R. E.: Ten years of shipboard ADCP measurements along the Northwestern Hawaiian Islands, Atoll Res. Bull 543, 347-363, 2006.

Flament, P.: The Ocean Atlas of Hawaii, School of Ocean and Earth Science and Technology, University of Hawaii, Honolulu, HI, 1996.

Ganeshram, R. S., Pedersen, T. F., Calvert, S. E., McNeill, G. W., and Fontugne, M. R.: Glacial-interglacial variability in denitrificaiton in the world's oceans: Causes and consequences, Paleoceanography, 15, 361-376, 2000.

Georicke, R. and Fry, B.: Variations of marine plankton $\delta^{1} 3 \mathrm{C}$ with latitude, temperature, and dissolved $\mathrm{CO} 2$ in the world ocean, Global Biogeochem. Cy., 8, 85-90, 1994.

Gruber, N., Keeling, C. D., and Stocker, T. F.: Carbon-13 constraints on the seasonal inorganic carbon budget at the BATS site in the northwestern Sargasso Sea, Deep-Sea Res. I, 45, 673-717, 1998.

Heikoop, J. M., Hickmott, D. D., Risk, M. J., Shearer, C. K., and Atudorei, V.: Potential climate signals from the deep-sea gorgonian coral Primnoa resedaeformis, Hydrobiologia, 471, 117124, 2002. 
Karl, D. M.: A sea of change: Biogeochemical Variability in the North Pacific Subtropical Gyre, Ecosystems, 2, 181-214, 1999.

Karl, D. M. and Lukas, R.: The Hawaii Ocean Time-series (HOT) program: Background, rationale and field implementation, Deep Sea Res. II, 43, 129-156, 1996.

Karl, D. M., Michaels, A., Bergman, B., Capone, D., Carpenter, E., Letelier, R., Lipschultz, F., Paerl, H., Sigman, D., and Stal, L.: Dinitrogen fixation in the world's oceans, Biogeochemistry, 57/58, 47-98, 2002.

Karl, D. M., Bidigigae, R. R.,Church, M. J., Dore, J. E., Letelier, R. M., Mahaffey, C., and Zehr, J. P.: The nitrogen cycle in the North Pacific Trades biome: An Evolving Paradigm, in: Nitrogen in the Marine Environment, edited by: Capone, D. G., Bronk, D. A., Mulholland, M. R., and Carpenter, E. J., Academic Press, 705769, doi:10.1016/B978-0-12-372522-6.00016-5, 2008.

Kienast, S. S., Calvert, S. E., and Pederson, T. F.: Nitrogen isotope and productivity variations along the northeast Pacific margin over the last 120 kyr: Surface and subsurface paleoceanography, Paleoceanography, 17, 1055, doi:10.1029/2001PA000650, 2002.

Kienast, M., Lehmann, M. F., Timmerman, A., Galbraith, E., Bolliet, T., Holbourn, A., Normandeau, C., and Laj, C.: A mid-Holocene transition in the nitrogen dynamics of the western equatorial Pacific: Evidence of a deepening thermocline?, Geophys. Res. Letts., 35, L23610, doi:10.1029/2008GL035464, 2008.

Kroopnick, P. M.: The dissolved $\mathrm{O}_{2}-\mathrm{CO}_{2}{ }^{-13} \mathrm{C}$ system in the eastern equatorial Pacific, Deep-Sea Res., 21, 211-227, 1974.

Kroopnick, P. M.: The distribution of ${ }^{13} \mathrm{C}$ of $\Sigma \mathrm{CO}_{2}$ in the world oceans, Deep-Sea Res., 32, 57-84, 1985.

Laws, E. A., Popp, B. N., Bidigare, R. R., Kennicutt, M. C., and Macko, S. A.: Dependence of phytoplankton carbon isotopic composition on growth rate and [CO2]aq: Theoretical considerations and experimental results, Geochim., Cosmochim. Acta, 59, 1131-1138, 1995.

Luo, Y-W., Ducklow, H. W., Friedrichs, M. A. M., Church, M. J., Karl, D. M., and Doney, S. C.: Interannual variability of primary productivity and dissolved organic nitrogen storage in the North Pacific Subtropical Gyre, J. Geophys. Res., 117, G03019, doi:10.1029/2011JG001830, 2012.

Maranon, E., Behrenfeld, M. J., González, N., Mouriño, B., and Zubkov, M. V.:. High variability of primary production in oligotrophic waters of the Atlantic Ocean: uncoupling from phytoplankton biomass and size structure, Mar. Ecol. Prog. Ser., 257, 1-11, 2003.

Osterberg, E., Mayewski, P., Kreutz, K., Fisher, D., Handley, M., Sneed, S., Zdanowicz, C., Zheng, J., Demuth, M., Waskiewicz, M., and Bourgeois, J.: Ice core record of rising lead pollution in the North Pacific atmosphere, Geophys. Res. Lett., 35, L05810, doi:10.1029/2007GL032680, 2008.

Quay, P. D. and Stutsman, J.: Surface layer carbon budget for the subtropical N, Pacific: $\mathrm{d}^{13} \mathrm{C}$ constraints at station ALOHA, Deep-Sea Res. Pt. I, 50, 1045-1061, 2003.

Rafter, P. A., Sigman, D. M., Charles, C. D., Kaiser, J., and Haug, G. H.: Subsurface tropical Pacific nitrogen isotopic composition of nitrate: Biogeochemical signals and their transport, Global Biogeochem. Cy., 26, GB1003, doi:10.1029/2010GB003979, 2012.

Reimer, P. J., Baillie, M. G. L., Bard, E., Bayliss, A., Beck, J. W., Blackwell, P. G., Bronk-Ramsey, C., Buck, C. E., Burr, G. S., Edwards, R. L., Friedrich, M., Grootes, P. M., Guilderson, T. P.,
Hadjas, I., Heaton, T. J., Hogg, A. G., Hughen, K. A., Kaiser, K. F., Kromer, B., McCormac, F. G., Manning, S., Reimer, R. W., Richards, D. A., Southon, J. R., Talamo, S., Turney, C. S. M., van der Plicht, J., and Weyhenmeyer, C. E.: Intcal09 and Marine09 Radiocarbon Age Calibration Curves, 0-50000 years CAL BP, Radiocarbon, 51, 1111-1150, 2009.

Roark, E. B., Guilderson, T. P., Flood-Page, S., Dunbar, R. B., Ingram, B. L., Fallon, S. J., and McCulloch, M.: Radiocarbonbased ages and growth rates of bamboo corals from the Gulf of Alaska, Geophys. Res. Lett., 32, doi:10.1029/2004GL021919, 2005.

Roark, E. B., Guilderson, T. P., Dunbar, R. B., and Ingram, B. L.: Radiocarbon based ages and growth rates: Hawaiian deep sea corals, Mar. Ecol. Prog. Ser., 327, 1-14, 2006.

Roark, E. B., Guilderson, T. P., Dunbar, R. B., Fallon, S., and Mucciarone, D. A.: Extreme longevity in proteinaceous deep-sea corals, Proc. Natl. Acad. Sci., 6, 5204-5208, doi:10.1073/pnas.0810875106, 2009.

Ryther, J. H.: Potential productivity of the sea, Science, 130, 602$608,1959$.

Sherwood, O. A., Heikoop, J. M., Scott, D. B., Risk, M. J., Guilderson, T. P., and McKinney, R. A.: Stable isotopic composition of deep-sea gorgonian corals Primnoa spp.: a new archive of surface processes, Mar. Ecol. Prog. Ser., 301, 135-148, 2005.

Sherwood O. A., Scott, D. B., and Risk, M. J.: Late Holocene radiocarbon dating and aspartic acid racemization dating of deepsea octocorals. Geochim. Cosmochim, Acta, 70, 2806-2814, doi:10.1016/j.gca.2006.03.011, 2006.

Sherwood O. A., Thresher, R. E., Fallon, S. J., Davies, D. M., and Trull, T. W.: Multi-century time-series of $15 \mathrm{~N}$ and $14 \mathrm{C}$ in bamboo corals from deep Tasmanian seamounts: evidence for stable oceanographic conditions, Mar. Ecol. Prog. Ser., 397, 209-218, 2009.

Sherwood, O. A., Lehmann, M. F., Schubert, C. J., Scott, D. B., and McCarthy, M. D.: Nutrient regime shift in the western North Atlantic indicated by compound-specific $\delta^{15} \mathrm{~N}$ of deepsea gorgonian corals, Proc. Nat. Acad. Sci., 108, 1011-1015, doi:10.1073/pnas.1004904108, 2011.

Sinninger, F., Ocaña, O. V., and Baco, A. R.: Diversity of Zoanthids (Anthozoa: Hexacorallia) on Hawaiian Seamounts: Description of the Hawaiian Gold Coral and Additional Zoanthids, PLoS ONE, 8, e52607, doi:10.1371/journa.pone.0052607, 2013.

Smith, J. J., Fischer, H., Wahlen, M., Mastroianni, D., and Deck, B.: Dual modes of the carbon cycle since the last glacial maximum, Nature, 400, 248-250, 1999.

Stanley, G. D. and Cairns, S. D.: Constructional Azooxanthellate coral communities: an overview with implications for the fossil record, Palaios, 3, 233-242, 1988.

Stuiver, M. and Polach, H. A.: Discussion reporting of ${ }^{14} \mathrm{C}$ data, Radiocarbon, 19, 355-363, 1977.

Tourre, Y. M., Rajagopalan, B., Kushnir, Y., Barlow, M., and White, W. B.: Patterns of coherent decadal and interdecadal climate signals in the Pacific Basin during the 20th century, Geophys. Res. Lett., 28, 2069-2072, 2001.

Uchikawa, J., Popp, B. N., Schoonmaker, J. E., Timmermann, A., and Lorenz, S. J.: Geochemical and climate modeling evidence for Holocene aridificaiton in Hawaii: dynamic response to a weakening equatorial cold tongue, Quat. Sci. Rev., 29, $3057-$ 3066, 2010. 
Wakeham, S. G., Lee, C., Hedges, J. I., Hernes, P. J., and Peterson, M. L.: Molecular indicators of diagenetic status in marine organic matter, Geochim. Cosmochim, Acta, 61, 5363-5369, 1997.

Warner, M. J., Bullister, J. L., Wisegarver, D. P., Gammon, R. J., and Weiss, R. F.: Basin-wide distributions of chlorofluorocarbons CFC-11 and CFC-12 n the North Pacific: 1985-1989, J. Geophys. Res., 101, 20525-20542, 1996.

Wheatcroft, R.A., Jumars, P. A., Smith, C. R., and Nowell, A. R. M.: A mechanistic view of the particulate biodiffusion coefficient: step lengths, rest periods, and transport directions, J. Mar. Res., 48, 177-207, 1990.
Williams, B., Risk, M. J., Ross, S. W., and Sulak, K. J.: Deep-water antipatharians: Proxies of environmental change, Geology, 34, 773-776, 2006.

Zaunbrecher, L. K., Cobb, K. M., Beck, J. W., Charles, C. D., Druffel, E. R. M., Fairbanks, R. G., Griffin, S., and Sayani, H. R.: Coral records of central tropical Pacific radiocarbon variability during the last millennium, Paleoceanography, 25, PA4212, doi:10.1029/2009PA001788, 2010.

Zhang, J. and Quay, P. D.: The total organic carbon export rate based on ${ }^{13} \mathrm{C}$ and ${ }^{12} \mathrm{C}$ of DIC budgets in the equatorial Pacific region, Deep-Sea Res. II, 44, 2163-2190, 1997. 